\title{
PERKEMBANGAN NEGARA HUKUM DEMOKRASI DITINJAU DARI ASPEK PENEGAKAN HUKUM ADMINISTRASI LINGKUNGAN HIDUP DI INDONESIA
}

\author{
Atika Thahira \\ Magister Ilmu Hukum Universitas Andalas \\ Jalan Pancasila, No.10, Kota Padang \\ Email: atikathahirawim@gmai.com
}

\begin{abstract}
The rule of law in Indonesia is often referred to as rechtstaats or the rule of law. Indonesia is a state of law listed in Article 1 paragraph (3) of the 1945 Constitution. That the element of democracy is the freedom of human rights, that every citizen enjoys basic rights, in a democracy every citizen can enjoy their basic rights freely. The development of a democratic law state in terms of environmental law enforcement aspects in Indonesia can be reviewed through organic state theory and pluralist state theory. Based on the theory of an organic state when looking at aspects of law enforcement for environmental administration in Indonesia, the state has approved the enforcement of environmental administration so that the state can approve every activity and / or business in the environmental field. Judging from the pluralist state theory In terms of this pluralist state theory the state accommodates a variety of diverse interests in society. All countries have accommodated all citizens' rights to a Good and Healthy Environment through pro-environment government policies.
\end{abstract}

Keywords; Rechtstaats, Environmental, Democratic.

\begin{abstract}
Abstrak
Negara hukum di Indonesia sering disebut dengan rechtstaats atau the rule of law. Indonesia dalah ngara hukum dicantumkan dalam Pasal 1 ayat (3) UUD 1945. Bahwa elemen dari demokrasi adalah adanya kebebasan HAM, bahwa setiap warga negara menikmati hak-hak dasar, dalam demokrasi setiap warga masyarakat dapat menikmati hak-hak dasarnya secara bebas. Perkembangan negara hukum demokrasi ditinjau dari aspek penegakan hukum administrasi lingkungan hidup di indonesi adalah dapat ditinjau melalui Teori negara organis dan Teori negara pluralis. Berdasarkan teori negara organis jika melihat dari aspek penegakan hukum administrasi lingkungan hidup di Indonesia negara telah mengatur mengenai penegakan sanksi administrasi lingkungan hidup dimana agar negara dapat mengatur mengenai setiap kegiatan dan/atau usaha dibidang lingkungan hidup. Dilihat dari teori negara pluralis Ditinjau dari teori negara pluralalis ini negara mengakomodasi berbagai kepentingan yang majemuk dalam masyarakat. Bahwa negara telah mengakomodir seluruh hak setiap warga negara atas lingkungan hidup yang baik dan sehat melalui kebijakan-kebijakan pemerintah yang pro lingkungan.
\end{abstract}

Kata Kunci; Negara Hukum, Lingkungan Hidup, Demokrasi. 


\section{PENDAHULUAN}

Tercantum dalam konstitusi bahwa Indonesia adalah negara hukum. ${ }^{1}$ Istilah negara hukum di Indonesia sering disebut dengan rechtstaats atau the rule of law. Paham rechtstaats pada dasarnya bertumpu pada sistem hukum Eropa Kontinental dan walaupun dalam UUD 1945 istilah negara hukum disebut rechtstaats, tetapi secara normatif harus dibedakan dengan paham negara hukum dalam sistem hukum Eropa Kontinental ataupun konsep the rule of law dalam sistem hukum Anglo Saxon. ${ }^{2}$

Menurut $\mathrm{Krabe}^{3}$, negara sebagai pencipta dan penegak hukum di dalam segala kegiatannya harus tunduk pada hukum yang berlaku. Dalam arti ini hukum membawahi negara. Berdasarkan pengertian hukum itu bersumber dari kesadaran hukum rakyat, maka hukum mempunyai wibawa yang tidak berkaitan dengan seseorang. Konsep negara hukum berkaitan dengan konsep demokrasi. Pelaksanaannya di Indonesia hukum dan demokrasi memiliki hubungan atau korelasi yang erat, dan pada perkembangannya paham negara hukum tidak dapat dipisahkan dari paham kerakyatan. Secara historis, gagasan tentang konsepsi negara hukum terus bergulir sejalan dengan arus perkembangan sejarah. Mulai dari konsepsi negara hukum liberal (nachwachter staat/negara sebagai penjaga malam) ke negara hukum formal (formele rechtsstaat) kemudian menjadi negara hukum materiil (materiele rechtsstaat) hingga pada ide negara kemakmuran (welvarstaat) atau negara yang mengabdi kepada kepentingan umum (social service state atau sociale verzorgingsstaat). ${ }^{4}$

Terkait demokrasi sebagai suatu gagasan politik merupakan paham yang universal sehingga di dalamnya terkandung beberapa elemen sebagai berikut: 5

1. Penyelenggara kekuasaan berasal dari rakyat;

2. Setiap pemegang jabatan yang dipilih oleh rakyat harus dapat mempertanggungjawabkan kebijaksanaan yang hendak dan telah ditempuhnya;

3. Diwujudkan secara langsung maupun tidak langsung;

1 Pasal 1 ayat (3) Undang-Undang Dasar Negara Republik Indonesia Tahun 1945.

2 Tengku Erwinsyahbana \& Tengku Rizq Frisky Syahbana, Perspektif Negara Hukum Indonesia Berdasarkan Pancasila, https://www.researchgate.net/publication/326138919 diakses pada 21 Desember 2019, Pukul 10.00 WIB.

3 Usep Ranawijaya, Hukum Tata Negara Dasar-Dasarnya, (Ghalia Indonesia, Jakarta, 1983). hlm. 181

4 Padmo Wahjono, Membudayakan UUD 1945, (IND HILL-Co, Jakarta, 1991). hlm. 73

5 Muntoha, Demokrasi dan Negara Hukum, JURNAL HUKUM NO. 3 VOL. 16 JULI 2009: 379 - 395. 
4. Rotasi kekuasaan dari seseorang atau kelompok ke orang atau kelompok yang lainnya, dalam demokrasi peluang akan terjadinya rotasi kekuasaan harus ada, dan dilakukan secara teratur dan damai;

5. Adanya proses pemilu, dalam negara demokratis pemilu dilakukan secara teratur dalam menjamin hak politik rakyat untuk memilih dan dipilih; dan

6. Adanya kebebasan Hak Asasi Manusia (HAM), menikmati hak-hak dasar, dalam demokrasi setiap warga masyarakat dapat menikmati hak-hak dasarnya secara bebas, seperti hak untuk menyatakan pendapat, berkumpul dan berserikat dan lain-lain. Dalam rangka mengimplementasikan semua.

Bahwa elemen dari demokrasi adalah adanya kebebasan HAM, bahwa setiap warga negara menikmati hak-hak dasar, dalam demokrasi setiap warga masyarakat dapat menikmati hak-hak dasarnya secara bebas.

Terkait dengan hak atas lingkungan hidup yang baik dan sehat bagi seluruh warga negara, bahwa saaat ini kata lingkungan kini menjadi sebuah kata yang menggetarkan sebagaimana dengan kata demokrasi dan hak asasi manusia (HAM). Lingkungan seolah menjadi sebagai sosok personal yang mendapatkan perlindungan hukum ("rechtsbecherming"/"legal protection"). Istilah hak atas lingkunga hidup yang baik dan sehat menjalar sebagai konsepsi yang musti diterima dengan segala konsekuensi hukumnya. Lingkungan pada akhirya diletakkan dalam takaran normatif yang konstitusional untuk mendapat perawatan yang layak sebagai bagian dari HAM yang elementer. ${ }^{6}$ Dalam Konstitusi Negara Republik Indonesia yang merupakan hukum dasar dalam sistem hukum positif Negara Republik Indonesia, Negara mengakui dan menjamin, bahwa lingkungan hidup yang baik dan sehat adalah hak asasi manusia sebagaimana yang dimuat dalam Pasal $28 \mathrm{H}$ ayat (1) Undang Undang Dasar Negara Republik Indonesia Tahun 1945, yaitu :

"Setiap orang berhak hidup sejahtera lahir dan batin, bertempat tinggal, dan mendapatkan lingkungan hidup yang baik dan sehat serta berhak memperoleh pelayanan kesehatan."

Penuangan "hak atas lingkungan hidup yang baik dan sehat" sebagai "subjective rights" merupakan bentuk perlindungan hukum paling "ekstensif". Mengingat bahwa

6 Suparto Wijoyo, 2009, Konstitusionalitas Hak Atas Lingkungan, (Airlangga University Press, Surabaya, 2009) hlm. 1. 
lingkungan hidup yang baik dan sehat adalah hak asasi manusia, maka dalam rangka penyelenggaraan negara, pemerintahan dan pembangunan untuk kesejahteraan bangsa Indonesia harus dijaga eksistesinya. Untuk menjaga eksistensi hak asasi atas lingkungan hidup yang baik dan sehat, salah satu prinsip penyelenggaraan perekonomian nasional Indonesia adalah berdasarkan prinsip berwawasan lingkungan sebagaimana yang diamanatkan dalam Pasal 33 ayat (4) Undang Undang Dasar Negara Republik Indonesia Tahun 1945 yang selanjutnya disebut sebagai UUD 1945, yaitu :

"Perekonomian nasional diselenggarakan berdasar atas demokrasi ekonomi dengan prinsip kebersamaan, efisiensi, berkeadilan, berkelanjutan, berwawasan lingkungan, kemandirian, serta dengan menjaga keseimbangan kemajauan dan kesatuan ekonomi nasional."

Selain menjadi salah satu prinsip penyelenggaraan perekonomian nasional, lingkungan hidup yang baik dan sehat juga menjadi landasan kebijakan pembangunan nasional yaitu pembangunan yang berwawasan lingkungan hidup yang berkelanjutan, terarah, dan terencana.

Maka, lingkungan hidup perlu dijaga kelestarian dan fungsinya melalui penegakan hukum, yaitu salah satunya penegaakan hukum lingkungan administrasi. Penegakan hukum administrasi memiliki potensi kuat sebagai perangkat pencegahan sebelum terjadinya pelanggaran yang serius dan menimbulkan dampak negatif terhadap kualitas lingkungan hidup. ${ }^{7}$ Aturan-aturan yang bersifat administrasi adalah memberi beban kepada warga masyarakat untuk mematuhi kewajiban yang ditetapkan pemerintah dalam rangka perlindungan dan pengelolaan lingkungan hidup dan alternatif penyelesaian sengketa lingkungan hidup.

Bahwa penegakan hukum administrasi lingkungan hidup di Indonesia dalam kaitannya dengan perkembangan negara hukum demokrasi adalah Walaupun hakhak dasar mengandung sifat membatasi kekuasaan pemerintahan, pembatasan tersebut tidak berarti mematikan kekuasaan pemerintahan yang pada dasarnya berisi wewenang untuk mengendalikan kehidupan masyarakat. ${ }^{8}$ Maka hal ini dapat ditinjau melalui Teori negara organis atau dengan Teori negara pluralis.

\footnotetext{
${ }^{7}$ Mas Achmad Santosa, Alam Pun Butuh Hukum \& Keadilan, (As@-Prima, Jakarta, 2006) .hlm. 89.

8 Ibid.
} 
Adapaun rumusan masalah dalam penelitian ini yaitu bagaimana aspek penegakan hukum administrasi lingkungan hidup di indonesia ? dan bagaimana perkembangan megara hukum demokrasi dalam aspek penegakan hukum administrasi lingkungan hidup di indonesia ditinjau dari teori negara organis dan teori negara pluralis.?

Selanjutnya yang menjadi tujuan dari penelitian ini meliputi untuk mengetahui aspek penegakan hukum administrasi lingkungan hidup di Indonesia, dan mengetahui perkembangan megara hukum demokrasi dalam aspek penegakan hukum administrasi lingkungan hidup di indonesia ditinjau dari teori negara organis dan teori negara pluralis. Untuk manfaat penelitian ini secara teoritis penelitian ini diharapkan dapat menjadi bahan informasi hukum bagi para akademisi bidang hukum, serta dapat berguna sebagai sumbangan pemikiran dalam ilmu hukum.

Penelitian ini diharapkan mampu memberikan sumbangan bagi pembangunan hukum khususnya dalam pengembangan hukum lingkungan tentang perkembangan megara hukum demokrasi dalam aspek penegakan hukum administrasi lingkungan hidup di indonesia ditinjau dari teori negara organis dan teori negara pluralis.

Metode pendekatan dalam penelitian ini menggunakan metode pendekatan yuridis normatif. Sifat penelitian yang digunakan adalah deskriptif-analitis, yaitu menggambarkan norma-norma yang diteliti dan dihubungkan dengan teori-teori, dan pendapat ahli hukum. Sumber data ddalam penelitian ini adalah Penelitian kepustakaan merupakan penelitian yang dilakukan berdasarkan buku-buku, literatur-literatur yang berkaitan dengan masalah yang akan diteliti.

\section{PEMBAHASAN}

\subsection{Aspek Penegakan Hukum Administrasi Lingkungan Hidup Di Indonesia}

Menurut Takdir Rahmadi, penegakan hukum lingkungan dapat dimaknai sebagai penggunaan atau penerapan instrumen-instrumen dan sanksi-sanksi dalam lapangan hukum administrasi, pidana, atau perdata dengan tujuan memaksa subjek hukum yang menjadi sasaran untuk mematuhi peraturan perundang-undangan lingkungan hidup. Penegakan hukum lingkungan administrasi adalah penerapan instrumen- 
instrumen dan sanksi-sanksi dalam lapangan hukum lingkungan administrasi untuk mematuhi peraturan perundang-undangan lingkungan hidup. ${ }^{9}$

Menurur Sukanda Husin, penegakan hukum lingkungan administrasi dianggap sebagai penegakan hukum lingkungan yang terpenting. Hal ini karena penegakan hukum lingkungan administrasi lebih ditujukan kepada upaya mencegah terjadinya pencemaran dan perusakan lingkungan. Di samping itu penegakan hukum lingkugan administrasi juga bertujuan untuk menghukum pelaku pencemaran dan perusakan lingkungan. ${ }^{10}$

Penegakan hukum lingkungan administrasi dapat dilakukan secara preventif dan represif. Penegakan hukum secara preventif dilakukan melalui pengawasan, sedangkan penegakan hukum secara represif dilakukan melalui penerapan sanksi administrasi. Pengawasan dan penerapan sanksi administrasi tersebut bertujuan untuk mencapai ketaatan masyarakat terhadap norma hukum lingkungan administrasi. ${ }^{11}$

Untuk penegakan hukum perlu ditetapkan sanksi sebagai penjamin agar ketentuan yang dibuat berlaku efektif. ${ }^{12}$ Sanksi administrasi adalah sanksi hukum yang dapat dijatuhkan oleh pejabat pemerintah tanpa melalui proses pengadilan atau litigasi terhadap seseorang atau badan hukum yang melanggar ketentuan hukum lingkungan administrasi. ${ }^{13}$ Sanksi administrasi terutama mempunyai fungsi instrumental, yaitu pengendalian perbuatan terlarang. Sanksi administrasi ditujukan kepada pencegahan dan penghentian pelanggaran. ${ }^{14}$

Dalam penerapan sanksi administrasi harus berpedoman kepada ketentuan Lampiran I angka IV Peraturan Menteri Lingkungan Hidup Nomor 02 Tahun 2013 tentang Pedoman Penerapan Sanksi Administratif di Bidang Perlindungan dan Pengelolaan Lingkungan Hidup.

Jenis sanksi administratif yaitu:

a. Teguran tertulis

\footnotetext{
9 Takdir Rahmadi Takdir Rahmadi, Hukum lingkungan di Indonesia, (PT Raja Grafindo Persada, Jakarta, 2011). hlm.. 207.

${ }^{10}$ Sukanda Husin, Penegakan Hukum Lingkungan Indonesia, (Sinar Grafika. Jakarta, 2009). hlm. 92.

11 Bachrul Amiq, Bachrul Amiq, Sanksi Administrasi Dalam Hukum Lingkungan, (Laks Bang, Yogyakarta, 2005). hlm. 1.

12 M. Ali Zaidin, Menuju Pembaruan Hukum Pidana, (Sinar Grafika, Jakarta, 2015). hlm. 10.

13 Takdir rahmadi, Op. Cit., hlm. 212.

${ }^{14}$ Bachrul Amiq, Op. Cit., hlm. 3.
} 
Diterapkan dalam hal usaha dan/atau kegiatan telah melakukan pelanggaran peraturan perundang-undangan dan persyaratan yang ditetapkan dalam izin. Pelanggaran tersebut secara tatakelola lingkungan hidup baik maupun secara teknis masih dapat dilakukan perbaikan dan belum menimbulkan pencemaran dan/atau kerusakan terhadap lingkungan hidup.

b. Paksaan Pemerintah

Tindakan nyata dari pemerintah untuk menghentikan pelanggaran dan/atau memulihkan dalam keadaan semula. Sanksi paksaan pemerintah diberikan dalam hal pelanggaran terhadap peraturan perundang-undangan dan/atau persyaratan dan kewajiban dalam izin. Penerapannya dapat dilakukan dengan terlebih dahulu diberikan teguran tertulis dan dapat pula tanpa didahului dengan teguran tertulis apabila pelanggaran yang dilakukan menimbulkan:

1) Ancaman yang serius bagi manusia dan lingkungan hidup;

2) Dampak yang lebih besar dan lebih luas jika tidak dihentikan pencemaran dan/atau perusakannya;

3) Kerugian yang lebih besar bagi lingkungan hidup jika tidak segera dihentikan pencemaran dan/atau perusakannya.

c. Pembekuan izin

Berupa tindakan hukum tidak memberlakukan sementara izin yang berakibat berhentinya usaha dan/atau kegiatan sementara, karena tidak melaksanakan paksaan pemerintah, melakukan kegiatan lain selain yang tercantum dalam izin, dan belum menyelesaikan secara teknis apa yang menjadi kewajibannya.

d. Pencabutan izin

Pencabutan izin karena tidak melaksanakan sanksi administrasi paksaan pemerintah, memindahtangankan izin usahanya kepada pihak lain tanpa persetujuan tertulis dari pemberi izin, pelanggaran yang menimbulkan pencemaran dan/atau kerusakan lingkungan hidup yang menimbulkan keresahan masyarakat.

e. Denda Administratif

Pembebanan kewajiban membayar sejumlah uang kepada penanggung jawab usaha dan/atau kegiatan karena lalai melaksanakan paksaan pemerintah. Prosedur penerapan sanksi administratif adalah: 
a. Prosedur penerapannya harus sesuai dengan peraturan yang menjadi dasarnya dan asas-asas umum pemerintahan yang baik;

b. Pejabat yang menerapkannya harus memilki kewenangan yang sah;

c. Ketepatan penerapan sanksi administrasi meliputi:

1) Berbentuk Keputusan Tata Usaha Negara;

2) Substansi itu berkaitan dengan:

a) Jenis dan peraturan yang dilanggar;

b) Jenis sanksi yang diterapkan;

c) Perintah yang harus dilaksanakan;

d) Jangka waktu;

e) Konsekwensi dalam hal sanksi administrasi tidak dilaksanakan; dan

f) Hal-hal lain yang relevan.

3) Tidak cacat yuridis dalam penerapannya yitu:

Hindari klausula pengamanan yang berbunyi, Apabila di kemudian hari ternyata ada kekeliruan da dalam Keputusan ini, maka akan diperbaiki sebagainana mestinya.

4) Asas kelesatarian dan keberlanjutan yaitu:

Bahwa setiap orang memikul kewajiban dan tanggungjawab terhadap generasi mendatang dan terhadap sesamanya dalam satu generasi dengan melakukan upaya pelestarian daya dukung ekosistem dan memperbaiki kualitas lingkungan hidup.

d. Mekanisme penerapan sanksi administrasi

1) Bertahap

Didahului dengan sanksi administrasi yang ringan hingga sanksi yang terberat. Apabila teguran tertulis tidak ditaati dikenakan sanksi yang lebih berat yaitu paksaan pemerintah. Apabila sanksi paksaan pemerintah tidak ditaati dikenakan sanksi lebih berat yaitu pembekuan izin. Apabila sanksi pembekuan izin tidak ditaati dikenakan sanksi yang lebih berat yaitu pencabutan izin.

2) Tidak bertahap

Adanya keleluasaan bagi pejabat yang berwenang untuk menentukan pilihan jenis sanksi didasarkan tingkat pelanggaran yang dilakukan. 
Apabila pelanggaran sudah menimbulkan pencemaran dan/atau kerusakan lingkungan hidup dapat dikenakan langsung sanksi paksaan pemerintah. Apabila sanski paksaan pemerintah tidak ditaati dapat dikenakan sanksi pencabuatn izin tanpa didahului dengan teguran tertulis.

3) Kumulatif

a) Kumulatif intenal adalah penerapan sanksi administrasi dengan menggabungkan beberapa jenis sanksi administrasi misalnya paksaan pemerintah digabungkan dengan pencabutan izin.

b) Kumulatif eksternal adalah penerapan sanksi administrasi dengan menggabungkannya dengan sanksi lainnya misalnya sanksi pencabutan izin digabungkan dengan sanksi pidana kurungan atau denda.

e. Penerapan sanksi administrasi ditetapkan dengan menggunakan keputusan tata usaha negara yang memuat:

1) Nama jabatan dan alamat pejabat administrasi yang berwenang;

2) Nama dan alamat penanggung jawab usaha dan/atau kegiatan yang melanggar;

3) Nama dan alamat usaha dan/atau kegiatan;

4) Jenis pelanggaran;

5) Ketentuan yang dilanggar;

6) Ruang lingkup pelanggaran;

7) Uaraian kewajibab atau perintah yang harus dilakukan penanggung jawab usaha dan/atau kegiatan;

8) Jangka waktu penaatan kewajiban penanggung jawab usaha dan/atau kegiatan;

9) Ancaman sanksi yang lebih berat apabila tidak melaksanakan perintah dalam sanksi.

f. Kewajiban pemberi sanksi

1) Menyampaikan keputusan sanksi dengan patut (waktu, cara, dan tempat) dan segera kepada penanggung jawab usahan dan/atau kegiatan; 
2) Memberikan penjelasan kepada pelanggar apabila diperlukan;

3) Melakukan pengawasan terhadap pelaksanaan sanksi;

4) Membuat laporan hasil penerapan sanksi.

g. Pengadministrasian keputusan sanksi administrasi

1) Penyusunan naskah keputusan dengan substansi dan format sesuai peraturan perundang-undangan;

2) penandatanganan oleh pejabat yang berwenang;

3) Pemberian nomor dan pengundangan;

4) Penyampaian kepada pihak yang berkepentingan;

5) Pembuatan tanda terima

\subsection{Perkembangan Negara Hukum Demokrasi Dalam Aspek Penegakan Hukum Administrasi Lingkungan Hidup Di Indonesia Ditinjau Dari Teori Negara Organis Dan Teori Negara Pluralis.}

Bahwa negara mengakui dan menjamin, lingkungan hidup yang baik dan sehat adalah hak asasi manusia sebagaimana yang dimuat dalam Pasal $28 \mathrm{H}$ ayat (1) Undang-Undang Dasar Negara Republik Indonesia Tahun 1945, yaitu :

"Setiap orang berhak hidup sejahtera lahir dan batin, bertempat tinggal, dan mendapatkan lingkungan hidup yang baik dan sehat serta berhak memperoleh pelayanan kesehatan."

Bahwa lingkungan hidup perlu dijaga kelestarian dan fungsinya melalui penegakan hukum. Sehingga perlu adanya penguatan dalam hal penegakan hukum dibidang lingkungan hidup.

Sebagaimana Undang-Undang Perlindungan dan Pengelolaan Lingkungan Hidup menyebutkan, bahwa "lingkungan hidup adalah kesatuan ruang dengan semua benda, daya, keadaan, dan makhluk hidup, termasuk manusia dan perilakunya, yang mempengaruhi alam itu sendiri, kelangsungan perikehidupan, dan kesejahteraan manusia serta makhluk hidup lain. Sedangkan "perlindungan dan pengelolaan lingkungan hidup adalah upaya sistematis dan terpadu yang dilakukan untuk melestarikan fungsi lingkungan hidup dan mencegah terjadinya pencemaran dan/atau kerusakan lingkungan hidup yang meliputi perencanaan, pemanfaatan, pengendalian, pemeliharaan, pengawasan, dan penegakan hukum. 
Demokratis dan partisipatif terhadap lingkungan hidup serta memberikan kesempatan kepada Kelompok yang menerjemahkan civil society sebagai 'masyarakat sipil' beranggapan hal ini memiliki relevansi erat dengan perjuangan demokratisasi di Indonesia. Hal ini sebagai counterbalancing terhadap negara, Masyarakat sipil diperhadapkan dengan negara Jadi, diperlukan masyarakat sipil yang kuat dan mapan sebagai alat penekan dan kontrol terhadap seluruh kebijakan negara. ${ }^{15} \mathrm{Hal}$ ini termasuk dalam kebijakan penegakan hukum administrasi lingkungan hidup di Indonesia.

Ditinjau dari Teori negara organis ini memandang bahwa negara memiliki kemandirian yang tinggi. Negara bukanlah suatu lembaga yang lemah sebagai hasil dari tuntutan dan kepentingan masyarakatnya semata. Negara cenderung berpikiran aktif mengambil kebijakan yang sangat rentan dengan keputusan yang tidak demokratis walaupun negara bertindak dengan tujuan dan atas nama kepentingan rakyatnya. Konsep negara ideal yang kuat dan sepenuhnya untuk kepentingan rakyat malah menjelma menjadi negara yang otoriter. Para elit penguasa berlomba-lomba memperebutkan kekuasaan dengan tujuan memenuhi kebutuhan material yang bersifat individual dan kelompok mereka saja. ${ }^{16}$ Dalam konsep negara organis, negara merupakan sebuah lembaga yang memiliki kemauan sendiri yang mandiri. Dia bukan sekadar alat dari keinginan sekelompok orang di masyarakat atau gabungan dari keinginan-keinginan kelompok yang ada di masyarakat.

Dikaitkan dengan teori negara organis jika melihat dari aspek penegakan hukum administrasi lingkungan hidup di Indonesia negara telah mengatur mengenai penegakan sanksi administrasi lingkungan hidup di Indonesia. ini dilakuakn agar negara dapat mengatur mengenai setiap kegiatan dan/atau usaha dibidang lingkungan hidup. Bahwa dengan adanya sanksi administrasi lebih efektif Penegakan hukum administrasi memiliki potensi kuat sebagai perangkat pencegahan sebelum terjadinya pelanggaran yang serius dan menimbulkan dampak negatif terhadap kualitas lingkungan hidup. ${ }^{17}$ Penerapan sanksi administratif lebih efektif dan efisien yaitu untuk mencegah terjadinya pelanggaran hukum, menghentikan pelanggaran,

15 Yety Rochwulaningsih, Dinamika Gerakan Lingkungan dan Global Environmental Governance, Jurnal Sejarah Citra Lekha, Vol. 2 , No. 2, 2017, hlm. 151-160.

${ }^{16}$ Amzulian, Teori Sifat hakikat Negara, (Tunggal Mnadiri Publishing, Malang, 2010). hlm. 8

17 Mas Achmad Santosa, Op. Cit., 89. 
dan pemulihan keadaan kepada keadaan semula sehingga penerapannya efektif. Sebagaimana menurut Mas Achmad Santosa, bahwa jika pencemaran dan perusakan lingkungan hidup telah terjadi maka akan sulit dan mahal untuk diatasi dan ditanggulangi. ${ }^{18}$

Sedangkan berdasarkan teori negara pluralis Teori ini memandang negara sebagai suatu lembaga yang harus dapat mengakomodasi berbagai kepentingan yang majemuk dalam masyarakat. Negara harus mampu menjadi perekat dari berbagai kelompok sosial politik yang beragam. Teori ini menekankan bahwa tidak mungkin suatu negara dapat berlangsung dengan baik apabila hanya mengutamakan kepentingan kelompok tertentu saja. Selain itu, tidak juga mungkin hanya kelompok kecil tertentu saja yang mampu mengendalikan negara. Dalam batas-batas tertentu memang tetap ada kelompok yang berupaya mendominasi negara. Namun secara fakta negara akan sulit untuk hanya tergantung atau dikendalikan oleh kelompok tertentu saja. ${ }^{19}$

Kaum pluralis memiliki suatu tesis bahwa negara merupakan alat dari masyarakat. Inilah kekuatan eksternal yang mengatur negara. Tetapi berbeda dengan marxisme yang mengatakan bahwa masyarakat didominasi oleh salah satu kelas. Sedangkan kaum pluralis berpendapat bahwa di masyarakat ada banyak kelompok yang berbeda kepentingannya. Tidak ada kelompok yang rerlalu dominan. Untuk menjadi mayoritas, kepentingan yang beragam ini melakukan kompromi. ${ }^{20}$

Ditinjau dari teori negara pluralalis ini negara mengakomodasi berbagai kepentingan yang majemuk dalam masyarakat. Bahwa adanya hak atas lingkungan hidup yang baik dan sehat bagi setiap warga negara telah mampu diakomodir oleh negara melalui kebijakan-kebijakan dalam penegakan hukum administrasi lingkungan hidup di Indoensia. Hal ini juga dalam rangka tetap menjalankan pembangunan dengan konsep sustainable development dengan tetap menjaga kelestarian dan fungsi lingkungan hidup.

Terkait dengan sustainable development atau pembangunan berkelanjutan adalah bahwa perluadanya demokratisasi lingkungan hidup bahwa Oekan S. Abdoellah, mengatakan kita membutuhkan pembangunan ekonomi, khususnya industrialisasi,
18 Ibid.
19 Ibid.
${ }^{20} \mathrm{Ibid}$. 
untuk meningkatkan taraf hidup masyarakat. Namun kita juga tidak boleh khilaf bahwa industrialisasi yang mengabaikan kondisi lingkungan malah akan berbalik menjadi bencana yang justru menghancurkan hasil-hasil pembangunan tersebut. Bagaimanapun, pembangunan merupakan proses yang terjadi di ruang hampa. Pembangunan, sudah senantiasa adala di dalam konteks dan bergantung pada daya dukung lingkungan yang melingkupinya. Pembangunan haruslah berkelanjutan. ${ }^{21}$

Menurut Dewan Riset Nasioanl Amerika yang berjudul Our Common Journey ialah alam, system daya dukung kehidupan, dan komunitas dan yang harus terbangun ialah manusia, perekonomian, dan masyarakat. Tujuan pembangunan ialah kesejahteraan dan kelangsungan hidup mahkluk selain manusia beserta ekosistemnya. ${ }^{22}$ Di Indonesia berkaitan dengan kebijakan yang berkaitan dengan lingkungan hidup secara normatif dapat dikutip dari pendapat menurut Otto Soemarwoto, secara normatif, kebijakan pembangunan berkelanjutan bertumpu pada empat hal utama, yakni penciptaan lapangann kerja (pro-job), pemberantasan kemiskinan (pro-poor), pertumbuhan ekonomi nasional (pro-growth), dan perlindungan lingkungan hidup (pro-environment). ${ }^{23}$

\section{PENUTUP}

\subsection{Simpulan}

Sanksi administrasi adalah sanksi hukum yang dapat dijatuhkan oleh pejabat pemerintah tanpa melalui litigasi terhadap seseorang atau badan hukum yang melanggar ketentuan hukum lingkungan administrasi. Sanksi administrasi terutama mempunyai fungsi instrumental, yaitu pengendalian perbuatan terlarang. Sanksi administrasi ditujukan kepada pencegahan dan penghentian pelanggaran. Dalam penerapan sanksi administrasi harus berpedoman kepada ketentuan Lampiran I angka IV Peraturan Menteri Lingkungan Hidup Nomor 02 Tahun 2013 tentang Pedoman Penerapan Sanksi Administratif di Bidang Perlindungan dan Pengelolaan Lingkungan Hidup.

21 Oekan S. Abdoellah, Pembangunan Berkelanjutan Di Indonesia di persimpangan jalan, (PT. Gramedia Pustaka Utama, Jakarta, 2016). hlm. 33.

22 Ibid.

${ }^{23} \mathrm{Ibid}$. 
Ditinjau dari teori negara organis jika melihat dari aspek penegakan hukum administrasi lingkungan hidup di Indonesia negara telah mengatur mengenai penegakan sanksi administrasi lingkungan hidup dimana agar negara dapat mengatur mengenai setiap kegiatan dan/atau usaha dibidang lingkungan hidup. Dilihat dari teori negara pluralis Ditinjau dari teori negara pluralalis ini negara mengakomodasi berbagai kepentingan yang majemuk dalam masyarakat. Bahwa negara telah mengakomodir seluruh hak setiap warga negara atas lingkungan hidup yang baik dan sehat melalui kebijakan-kebijakan dalan penegakan hukum administrasi lingkungan hidup di Indonesia.

\subsection{Saran}

Adanya penguatan dalam penegakan hukum dibidang lingkungan hidup terutama dalam penegakan hukum administrasi lingkungan hidup, karena hal ini lebih efektif dalam penerapannya tanpa harus dilakukan melalui proses litigasi yang memakan waktu cukup lama. Berdasarkan teori negara organis dan teori negara pluralis negara diharapkan dapat selalu mengeluarkan kebijakan-kebijakan yang dapat mengakomodir hak setiap warga negara Indonesia atas lingkungan hidup yang baik dan sehat sebagaimana yang di tuangkan dalam Pasal 28 H ayat (1) UUD 1945, terutama mengenai dalam bidang pengekan hukum admministrasi lingungan hidup.

\section{DAFTAR PUSTAKA}

Amiruddin \& Zainal Asikin, Pengantar Metode Penelitian Hukum, Jakarta: PT Raja Grafindo Persada, 2004.

Amzulian, Teori Sifat hakikat Negara, Malang: Tunggal Mnadiri Publishing, 2010.

Bachrul Amiq, Bachrul Amiq, Sanksi Administrasi Dalam Hukum Lingkungan, Yogyakarta: Laks Bang, 2005.

M. Ali Zaidin, Menuju Pembaruan Hukum Pidana, Jakarta: Sinar Grafika, 2015.

Mas Achmad Santosa, Alam Pun Butuh Hukum \& Keadilan, Jakarta: As@-Prima, 2006.

Muntoha, Demokrasi dan Negara Hukum, JURNAL HUKUM NO. 3 VOL. 16 JULI 2009: $379-395$.

Oekan S. Abdoellah, Pembangunan Berkelanjutan Di Indonesia di persimpangan jalan, Jakarta: PT. Gramedia Pustaka Utama, Jakarta, 2016. 
Padmo Wahjono, Membudayakan UUD 1945, jakarta: IND HILL-Co, 1991.

Sukanda Husin, Penegakan Hukum Lingkungan Indonesia, Jakarta: Sinar Grafika, 2009.

Suparto wijoyo, Konstitusionalitas Hak Atas Lingkungan, Surabaya: Airlangga University Press, Surabaya, 2009.

Tengku Erwinsyahbana \& Tengku Rizq Frisky Syahbana, Perspektif Negara Hukum Indonesia Berdasarkan

Pancasila, https://www.researchgate.net/publication/326138919.

Undang-Undang Dasar Negara Republik Indonesia Tahun 1945.

Usep Ranawijaya, Hukum Tata Negara Dasar-Dasarnya, Jakarta: Ghalia Indonesia, Jakarta, 1983.

Takdir Rahmadi Takdir Rahmadi, Hukum lingkungan di Indonesia, Jakarta: PT Raja Grafindo Persada, 2011.

Yety Rochwulaningsih, Dinamika Gerakan Lingkungan dan Global Environmental Governance, Jurnal Sejarah Citra Lekha, Vol. 2 , No. 2, 2017, hlm. 151-160. 